\title{
Long-term changes (1977 to 1987) in a muddy fine sand Abra alba-Melinna palmata community from the Western English Channel: multivariate time-series analysis
}

\author{
Fréderic Ibanez ${ }^{1}$, Jean-Claude Dauvin ${ }^{2}$ \\ ${ }^{1}$ C.E.R.O.V., Station Zoologique, BP 28, F-06230 Villefranche-sur-Mer, France \\ ${ }^{2}$ Station Biologique de Roscofi, CNRS-LP 4601 et Université P. \& M. Curie (Paris VI), F-29211 Roscoff, France
}

\begin{abstract}
Long-term monitoring for 10 yr (1977 to 1987) of the muddy fine sand community of the Bay of Morlaix ( $N$ France) has allowed us to determine the principal stages of structural succession following pollution by the hydrocarbons of the 'Amoco Cadiz' (1978). Abundance of 30 main species and biomasses of 30 categories were investigated. Regular series were obtained by averaging values from each season, resulting in 40 sequential observations. General trends and seasonal variations were extracted by the Eigen-Filtering method which takes into account the shortsess of the annual sampling. Principal component analysis of the covariance matrix of the general trends exhibits 7 successive periods of temporal community changes. This succession is a function of changes in direction in gradients within the populations. The community developed through a successional phase following the oil spill, with establishment at first of a community of opportunists, followed by a colonisation of the polychaete Lanice conchilega and finally by reestablishment of the original community pre-Amoco Cadiz. An attempt to classify the species according to their seasonal variations is proposed using a semiquantitative approach. Results show a concentration of maximal abundances in summer and autumn, and of minimal abundances in winter. The dissimilarity correlograms of the densities and the biomasses were used after rearranging the species into 3 trophic groups. The different behaviour of trophic groups is related to recolonization after the oil spill and to organic matter in the sediment.
\end{abstract}

\section{INTRODUCTION}

In 1977, we started a quantitative survey of 2 infralittoral fine and muddy fine sand communities of the Bay of Morlaix (Brittany, N France). The fine sand Abra alba - Hyalinoecia bilineata community is from 'Pierre Noire', and the muddy fine sand Abra alba Melinna palmata community is from the 'Rivière de Morlaix'. At that time the communities were in their natural conditions, characterized by small annual and multi-annual variations in their hydrologic and hydrodynamic characteristics. One year later, the 'Amoco Cadiz' oil spill (March 1978) introduced a vast, accidental disturbance of the sub-littoral communities in Northern Brittany. The perturbation was more pronounced in the fine sediment communities (Cabioch et al. 1978, 1980, 1982, Dauvin 1979, 1982). In the fine sand community at Pierre Noire, there were qualitative and quantitative abrupt, drastic changes after the stress (Cabioch et al. 1978, 1980). The number of species decreased to about $20 \%$, the density to about $80 \%$ and the biomass to about $40 \%$. In the muddy fine sand community at the 'Rivière de Morlaix' the impact of this pollution was more limited; it was characterized by a decrease in the number of amphipod species.

The short-term changes in these 2 fine sediment communities living in unpolluted conditions, from spring 1979 at 'Pierre Noire' and from summer 1980 at 'Rivière de Morlaix', have been well documented (Cabioch et al. 1980, 1982, Dauvin 1982, 1984). However, structural modifications were still perceptible 3 yr after the pollution occurred. Therefore, a continuous survey of these 2 stations has been carried out since 1980 to determine their long-term changes in natural conditions.

In a previous paper (Dauvin \& Ibanez 1986) we 
described long-term changes at the first station, the fine sand community at Pierre Noire. Its monitoring for 8 yr (1977 to 1985) allowed us to determine the main stages in its structural succession. The rapid changes in the community during the first $4 \mathrm{yr}$ after the 'Amoco Cadiz' oil spill showed a period of perturbation followed by the stabilisation of the macrobenthos. This development was a function of changes in the directions of gradients within the populations, related to the lack of recruitment, biostimulation and proliferation, regression, recolonisation and reconstitution of the populations affected by the oil spill.

This paper presents the results of the $10 \mathrm{yr}$ study (1977 to 1987) of temporal variations at the second station, the muddy fine sand community at 'Rivière de Morlaix'. In this study, we have used a quarterly sampling period which is generally sufficient to show general trends in the community. Because the number of observations is low, some time-series analysis techniques such as spectral analysis cannot be used. Therefore, the data have been analysed by the Eigenvector Filtering method used for planktonic time-series (Colebrook 1978). This method, which derives multiannual trends from seasonal and random variations, may be appropriate to series with a limited number of observations. Principal components analysis (PCA) of the covariance matrix of the extracted general trends (first filtering variable, FV) permits identification of 7 principal phases in the long-term changes of the community. $\mathrm{ABC}$ (Abundance Biomass Comparison) curves (Warwick 1988) have been used to detect the effects of the oil spill. An attempt to classify species according to their seasonal variations (second FV) is proposed using a semi-quantitative approach. Finally, changes of the species composition of the trophic groups in the timescale domain are presented using a multivariate extension of a structural function, the distogram.

\section{MATERIALS AND METHODS}

Study site. The sampling station 'Rivière de Morlaix' $\left(48^{\circ} 39^{\prime} 16^{\prime \prime} \mathrm{N}, 3^{\circ} 52^{\prime} 04^{\prime \prime} \mathrm{W}\right)$ lies in the middle of the navigational channel at the eastern border of the Morlaix estuary. The depth is $10 \mathrm{~m}$ at low tide. Because the station is located near the mouth of the estuary, the bottom waters show only a very slight dilution during the maximum river discharge in winter and spring (salinity: 33.95 in the bottom layers in March 1982; 32.20 in the bottom layers in June 1984). Salinity ordinarily ranges from 34.00 in winter to 35.10 at the end of summer. Bottom temperatures range from $8^{\circ} \mathrm{C}$ in winter to $16^{\circ} \mathrm{C}$ in summer. The difference between the winter and summer extremes of water temperature in the bottom layers usually does not exceed $8^{\circ} \mathrm{C}$ in 1986 , however, it was $10^{\circ} \mathrm{C}$, due to a severe winter $\left(5.8^{\circ} \mathrm{C}\right.$ at the bottom layers in March). The sediment at the sampling site is a mixture of fine sand and mud $(32 \%$ of the sediment consists of particles between 63 and $125 \mu \mathrm{m}$ ). The mean median size is equal to $93 \pm 14 \mu \mathrm{m}$ ( 20 analyses); the fraction smaller than $45 \mu \mathrm{m}$ averages $13.5 \pm 5.7 \%$. The station is rich in organic matter: particulate organic carbon accounts for $1.39 \%$ of the sediment dry weight (Beslier 1981).

Forty-nine samples were collected during the $10 \mathrm{yr}$ survey (August 1977 to June 1977), i. e. 4 to 6 observations in each annual cycle (from summer to next spring), at 2 to 3 mo intervals. For the samples of August 1977 and August 1978 a Hamon grab was used. It was operated 4 times, covering a surface area of $1.2 \mathrm{~m}^{2}$. For the other 47 samples, a Smith-McIntyre grab was used. This was operated 10 times covering a total surface area of $1 \mathrm{~m}^{2}$. The sampling efficiency of both grabs on the community was similar (Dauvin 1979).

After collection, the sediment was sieved $(1 \mathrm{~mm}$ circular mesh) and the retained material was fixed with $10 \%$ neutral formalin and sorted twice. The second sorting was done after staining with $10 \%$ Rose Bengal. The density of the different species ( $N$ ind. $\mathrm{m}^{-2}$ ) and the biomass of the principal species or zoological group (dry weight after decalcification and drying at $110^{\circ} \mathrm{C}$ : $B \mathrm{gm}^{-2}$ ) were recorded.

Selection of biological descriptors. The data represent $10 \mathrm{yr}$ of irregular sampling units (49). Regular series were obtained by averaging the values from each season, resulting in 40 successive observations. Mathematical treatments were used with the 30 most abundant species. These species represented about $80.3 \%$ of the total information (following Legendre \& Legendre 1979).

The 30 main species were ranked into 3 trophic groups: $M$, mixed (suspension feeders and surfacedeposit feeders); SSD, subsurface-deposit feeders; $C$, carnivores/omnivores. Their main characteristics are indicated in Table 1.

Biomasses were considered after grouping them into 30 taxonomic units, which eliminated scarce species or species with large individual biomass (Table 2).

Mathematical methods. Multiannual series are often considered as a mixture of 3 components: the general trend, the seasonal cycle and white noise. Given the paucity of observations per year (only 4), it seemed inadequate to extract the trend by classical polynomial adjustment or by moving averages. We thus used the Eigenvector Filtering method proposed by Colebrook (1978).

Taking a series $x_{t}, t$ varying between 1 and $N$, and a shift time interval $\tau$, one first constructs a matrix of data $\mathrm{X}$ corresponding to $m$ differentiated series (the choice 
Table 1. Statistical characteristics of the 30 main abundant species (densities in $\mathrm{N} \mathrm{m}^{-2}$ ) for the 40 observations

\begin{tabular}{|c|c|c|c|c|c|c|}
\hline Species & $\begin{array}{l}\text { Species No. } \\
\text { in analysis }\end{array}$ & $\begin{array}{c}\text { Total } \\
\text { number }\end{array}$ & $\begin{array}{c}\text { Mean } \\
\text { density }\end{array}$ & $\begin{array}{l}\text { Minimum } \\
\text { density }\end{array}$ & $\begin{array}{l}\text { Maximum } \\
\text { density }\end{array}$ & Frequency \\
\hline \multicolumn{7}{|c|}{ Mixed (suspension and surface-deposit feeders) } \\
\hline Chaetozone setosa Malmgren & 1 & 67854 & 1696.35 & 5 & 8100 & 100 \\
\hline Melinna palmata Grube & 2 & 20478 & 511.95 & 111 & 1613 & 100 \\
\hline Polydora antennata Claparède & 3 & 7357 & 183.93 & 0 & 1782 & 95 \\
\hline Mediomastus fragilis Rasmussen & 4 & 6238 & 155.95 & 5 & 512 & 100 \\
\hline Lanice conchilega (Pallas) & 5 & 5074 & 126.85 & 0 & 387 & 95 \\
\hline Tharyx marioni (de Saint-Joseph) & 6 & 4695 & 117.38 & 0 & 429 & 97 \\
\hline Abra alba (Wood) & 7 & 1548 & 38.70 & 0 & 266 & 97 \\
\hline Ampelisca brevicornis (Costa) & 8 & 1092 & 27.30 & 0 & 153 & 78 \\
\hline Thyasira flexuosa Montagu & 9 & 1240 & 31.00 & 3 & 86 & 100 \\
\hline Spio filicornis (Müller) & 10 & 1027 & 25.68 & 0 & 114 & 93 \\
\hline Polycirrus $\mathrm{sp}$ & 11 & 337 & 8.43 & 0 & 29 & 93 \\
\hline Arenicola marina (L.) & 12 & 243 & 6.08 & 0 & 95 & 38 \\
\hline \multicolumn{7}{|l|}{ Subsurface-deposit feeders } \\
\hline Clymene oerstedii Claparède & 13 & 3271 & 81.78 & 14 & 159 & 100 \\
\hline Notomastus latericeus Sars & 14 & 2246 & 56.15 & 11 & 240 & 100 \\
\hline Capitella capitata (Fabricius) & 15 & 493 & 12.32 & 0 & 339 & 55 \\
\hline Leiochone clypeata de Saint Joseph & 16 & 472 & 11.80 & 0 & 89 & 93 \\
\hline Harpinia pectinata Sars & 17 & 387 & 9.68 & 0 & 81 & 45 \\
\hline Aora typica Kröyer & 18 & 260 & 6.50 & 0 & 72 & 70 \\
\hline Oligochaetes & 19 & 256 & 6.40 & 0 & 49 & 65 \\
\hline Phascolion strombi (Montagu) & 20 & 253 & 6.33 & 0 & 43 & 57 \\
\hline Eudorella truncatula (Bate) & 21 & 194 & 4.85 & 0 & 39 & 70 \\
\hline Cheirocratus intermedius Sars & 22 & 162 & 4.05 & 0 & 22 & 70 \\
\hline \multicolumn{7}{|l|}{ Carnivores/omnivores } \\
\hline Nephtys hombergui Savigny & 23 & 7277 & 181.93 & 10 & 597 & 100 \\
\hline Eulalia sanguinea Oersted & 24 & 1675 & 41.88 & 0 & 126 & 93 \\
\hline Phyllodoce groëndlandica Oersted & 25 & 1313 & 32.83 & 0 & 366 & 93 \\
\hline Harmothoe lunulata (Della Chiaje) & 26 & 1112 & 27.80 & 0 & 93 & 95 \\
\hline Eteone longa Fabricius & 27 & 754 & 18.85 & 0 & 77 & 88 \\
\hline Leucothoe incisa Robertson & 28 & 556 & 13.90 & 0 & 35 & 93 \\
\hline Exogone hebes (Webster \& Benedict) & 29 & 409 & 10.22 & 0 & 46 & 85 \\
\hline Ophiura albida (Forbes) & 30 & 289 & 7.23 & 0 & 53 & 88 \\
\hline
\end{tabular}

of $\tau$ is considered below), then one extracts the $m$ eigenvalues and eigenvectors of the $m \times m$ covariance matrix and computes the principal components.

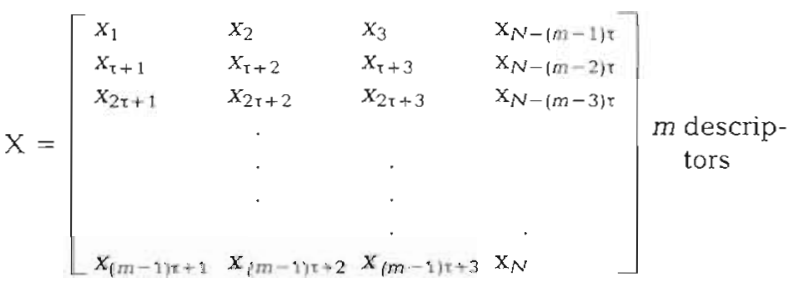

Takens (1981) showed that the cloud of the $N-(m-1) \tau$ values defined by the data matrix in the component space describes the trajectory of the biological system. In other words principal components must be considered as phase variables, not as chronological variables. The first component represents what is common for all the $m$ series and therefore is similar to the general trend of the series $x_{t}$. The second component corresponds to residual information after removing the trend. If a seasonal cycle is present it will be associated with the variation of this second component.

The analytical value of such decomposition depends on a judicious choice of $\tau$ and $m$. If $\tau$ and $m$ are too short, the maximum delay between the differentiated series $(\Delta t=(m-1) \tau)$ would be also very weak. Since the trend will contain most of the total variance, the residual components will represent only random variations. On the contrary if $\Delta t$ is too large, the trend will be independent of the structure of the series and will tend towards white noise. $\Delta t$ must then be selected as the value just less than the shortest significant cycle of the series. The first rise of the autocorrelation function may be an aid to determining this parameter. With our data the choice was obvious because only the seasonal cycle may correspond to the shortest cycle. Thus we took $m$ $=4$ and $\tau=1$. So the maximum time lag $\Delta t$ was 3 which is just less than the annual period of 4 intervals.

To obtain time variables (we will call them filtering variables, $F V$ ) it is necessary to estimate the $X$ data 
Table 2. Characteristics of the biomass $\left(\mathrm{mg} \mathrm{m}^{-2}\right)$ of the principal species and taxonomic units, for the 40 observations

\begin{tabular}{|c|c|c|c|c|}
\hline Species & Total biomass & Mean biomass & Minimum biomass & Maximum biomass \\
\hline \multicolumn{5}{|l|}{ Mixed } \\
\hline C. setosa & 16154 & 403.85 & 1 & 1688 \\
\hline L. conchilega & 198512 & 4962.80 & 0 & 17623 \\
\hline M. fragilis & 1425 & 35.63 & 0 & 194 \\
\hline M. palmata & 70327 & 1758.18 & 288 & 9198 \\
\hline$P$. antennata & 11194 & 279.85 & 0 & 2953 \\
\hline Polycirrus sp. & 3881 & 97.03 & 0 & 456 \\
\hline S. filicornis & 76 & 1.90 & 0 & 9 \\
\hline T. marioni & 531 & 13.28 & 0 & 42 \\
\hline Sedentary polychaetes & 3352 & 83.80 & 2 & 272 \\
\hline A. alba & 12030 & 300.75 & 0 & 3281 \\
\hline$T$ flexuosa & 1241 & 31.02 & 1 & 97 \\
\hline Bivalves & 945 & 23.63 & 0 & 156 \\
\hline Gastropods & 308 & 7.70 & 0 & 58 \\
\hline A. brevicomis & 832 & 20.80 & 0 & 112 \\
\hline \multicolumn{5}{|l|}{ Subsurface-deposit feeders } \\
\hline C. oerstedii & 41951 & 1048.78 & 45 & 2262 \\
\hline N. latericeus & 62411 & 1560.28 & 26 & 6599 \\
\hline Amphipods & 388 & 9.70 & 1 & 39 \\
\hline Peracarid crustaceans & 53 & 1.33 & 0 & 10 \\
\hline Miscellaneous & 1395 & 34.88 & 0 & 255 \\
\hline \multicolumn{5}{|l|}{ Carnivores/omnivores } \\
\hline E. sanguinea & 823 & 20.57 & 0 & 107 \\
\hline N. hombergii & 58557 & 1463.93 & 240 & 3894 \\
\hline P. groënlandica & 547 & 13.68 & 0 & 164 \\
\hline H. lunulata & 6200 & 155.00 & 0 & 474 \\
\hline Errant polychaetes & 5012 & 125.30 & 1 & 510 \\
\hline N. reticulatus & 4054 & 101.35 & 0 & 646 \\
\hline Pagurus spp. & 20609 & 515.23 & 0 & 2894 \\
\hline Decapod crustaceans & 1128 & 28.20 & 0 & 233 \\
\hline Acrocnida brachiata (Montagu) & 43 & 1.07 & 0 & 17 \\
\hline O. albida & 100 & 2.50 & 0 & 28 \\
\hline Other echinoderms & 279 & 6.98 & 0 & 124 \\
\hline
\end{tabular}

matrix, multiplying each component $c_{i}$ by its corresponding eigenvector $v_{j}: \mathrm{X}=v_{i} c_{j}$.

The data matrix represented above contains the same observation several times. Taking $m=4$ and $\tau=1$, the observation numbered 4 , for instance, is at the 4 th column of the first row, at the 3rd for the second, at the 2nd for the third and at the 1st for the last row. So in order to reconstruct a unique time series we have to average these 4 values. The observations numbered between 4 and 37 are represented 4 times in the matrix; the others are represented only 3 or 2 times. The first and the last are represented only once. Two important properties result from this averaging : the FVs are still not exactly orthogonal and their variance is different to the eigenvalues. The first consequence is probably more realistic than a rough independence of the components because the seasonal variation appears on the data curves correlated to the intensity of the trend. The second requires that in order to test the quality of the decomposition, one has to consider only the variance explained by the FV.
Grouping the species by the general trends. The first FVs are smoothed variables. Thus PCA of their correlation matrix permits an ordination of the species and the observations. This last representation in the reduced factorial space will respect the temporal contiguity of the observations (Ibanez 1983).

Grouping the species by their seasonal variations. The second FV presents very irregular profiles. The seasonal cycle may be absent during several years or shifted from one year to the next. A local study by semiquantitative methods seemed more suitable than a global approach. With 4 observations each year, seasonal cycles may be detected by one maximum value only. Kendall (1973) cemonstrated that the mean number of turning points (peaks and hollows) for a random series of length $N$ is equal to $2 / 3(N-2)$ and with a standard deviation of $\mathrm{SD}=\sqrt{(16 N-29) / 90}$

With $N=40$ one obtains 25 turning points and the standard deviation is $\mathrm{SD}=2.6$. At the $5 \%$ probability level the number of peaks belongs in the interval $12.5 \pm 2.6(., ; 0 ; 1)$. In this study, the number of peaks 
corresponding to the annual cycles in our case was theoretically 10 . Since this value is close to 12.5 , we considered that the above standard deviation represents a criterion to test the regularity of the annual cycle. If a species showed a number of peaks not included between $10 \pm 2.6$ ( 8 and 12), then it did not present a permanent seasonal cycle.

Also the percentage of explained variance by the second $\mathrm{FV}$ is an indication of the importance of the seasonal variations.

The Abundance Biomass Comparison (ABC method of Warwick 1986). Warwick (1986) suggested that the relative position of the cumulative ordered abundances curve compared to that of the cumulative ordered biomass ( $x$-axis logarithmic scale, $y$-axis percentage dominancel indicates natural physical and biological disturbance as well as pollution-induced disturbance. Undisturbed populations show a cumulative biomass curve lying above the cumulative abundance curve; with moderate disturbance effects the 2 curves coincide approximately, whereas the biomass curve lies below the number curve in the case of grossly polluted communities. The ABC method was used in an attempt to quantify the effect of the pollution and the level of maturity of the benthic community.

Structure function: the distogram. The distogram function was first used in plankton ecology by Mackas (1984) and by Ibanez \& Boucher (1987) and in benthos by Dauvin \& Ibanez (1986). It is a multivariate extension of the variogram function (Matheron 1974). A variogram gives the variance of a variable at different time (or space) scales $(h)$ :

$$
V(h)=\frac{1}{2 N(h)} \sum_{j}\left(x_{j+h}-x_{j}\right)^{2}
$$

$N(h)$ corresponds to the number of points separated by a distance $h$. Taking the squared chord length distance $\bar{d}^{2}$ between stations at different intervals $h$, a dissimilarity function called a distogram was defined, giving the importance of scalar changes of the faunistic assemblage in a community (Dauvin \& Ibanez 1986):

$$
\bar{d}^{2}(h)=\frac{1}{2 N(h)} \sum_{j} d_{j, j+h}^{2}
$$

In this study, the distogram function was used to estimate the community changes among each trophic group during the 10 yr survey.

\section{RESULTS}

\section{Composition of the macrobenthic fauna}

A total of 276 species were found in the 49 samples collected during the $10 \mathrm{yr}$ chronological series. Eightynine species $(32 \%)$ were present only on 1 or 2 occa- sions. Sixty-three species $(23 \%)$ had a frequency greater than $50 \%$. The 3 principal taxonomic groups totalled $92 \%$ of the species number: polychaetes, $41.2 \%$, molluscs, $15.3 \%$ and crustaceans, $35.6 \%$. Polychaetes represented more than $97.5 \%$ of the mean density, and $93 \%$ of the mean decalcified dry weight in the community. Molluscs accounted for $1.8 \%$ and $2.7 \%$ and crustaceans for $0.35 \%$ and $4.0 \%$ of the mean density and the decalcified dry weight, respectively. For the whole sampling period (August 1977 to June 1987), the mean density was 3523 ind. $\mathrm{m}^{-2}$ (varying from 1062 ind. $\mathrm{m}^{-2}$ in March 1985 to 12223 ind. $\mathrm{m}^{-2}$ in August 1982) and the mean decalcified dry weight, not considering the rare species with large individual weights, was $13.6 \mathrm{~g} \mathrm{~m}^{-2}$ (variations from $1.9 \mathrm{~g} \mathrm{~m}^{-2}$ in June 1986 to $32.7 \mathrm{~g} \mathrm{~m}^{-2}$ in October 1982).

The density and decalcified dry weight of the community showed seasonal variations, with a summer maximum and a winter minimum. Few species sensitive to hydrocarbons (amphipods) were represented before the pollution. This resulted in a negligible initial mortality for this community. The principal phenomena after the oil spill (levels of hydrocarbons higher than 100 ppm until summer 1979; 1443 ppm in August 1978) were a significant increase of the detrivorous populations and a proliferation of opportunistic species (Dauvin 1982).

\section{Eigenvector filtering}

Table 3 shows for each species the percentages of explained variances. Three categories were recognizable:

(1) Species with a similar percentage of variance for both FV $(+,+)$ : Chaetozone setosa, Abra alba, Spio filicornis, Capitella capitata and Phyllodoce groënlandica. They exhibited only seasonal variations or erratic events. A. alba (Fig. 1a) showed the same profile for the trend and the seasonal movement. C. setosa (Fig. 1b) had a similar behaviour during the first $8 \mathrm{yr}$, but some differences appeared during the 2 last years.

(2) Species with a trend strongly dominant trend $(++, \quad$ o): Polydora antennata, Lanice conchilega, Tharyx marioni, Clymene oerstedii, Leiochone clypeata, Harpinia pectinata, Nephtys hombergii, Eulalia sanguinea, Harmothoe lunulata, Eteone longa, Leucothoe incisa and Exogone hebes. The time scale of the changes was greater than $1 \mathrm{yr}$. The weak percentage of variance of the second FV indicated that the seasonal variation was not always present (Species Nos. $5,16,17,23$ ) or that its intensity was very fluctuating $(3,6,13,24,26,27,28,29)$. L. conchilega (Fig. 2a) showed a bell-shaped trend. The second FV presented a pseudoannual cycle at a time when the general trend 
Table 3. Percentage of variance explained by the first 2 filtering variables. Cumulative percentages; relative dominance between the trend and the seasonal variation. $(++, 0)$ : less than $1 \%$ of the variance explained by seasonal variations. $(++,+):$ more than $10 \%$ of deviation between the 2 percentages. $(+,+):$ less than $10 \%$

\begin{tabular}{|c|c|c|c|c|c|c|}
\hline \multirow{2}{*}{$\begin{array}{l}\text { Species } \\
\text { No. in } \\
\text { analyses }\end{array}$} & \multirow[t]{2}{*}{ Species } & \multirow{2}{*}{$\begin{array}{c}\text { First filtering } \\
\text { variable }\end{array}$} & \multirow{2}{*}{$\begin{array}{c}\text { Second filtering } \\
\text { variable }\end{array}$} & \multirow[t]{2}{*}{ Total } & \multicolumn{2}{|c|}{ Relative dominance } \\
\hline & & & & & Trend & $\begin{array}{l}\text { Seasonal } \\
\text { variation }\end{array}$ \\
\hline 1 & C. setosa & 15 & 15 & 30 & + & + \\
\hline 2 & M. palmata & 33 & 17 & 50 & ++ & + \\
\hline 3 & P. antennata & 53 & 0.6 & 54 & ++ & 0 \\
\hline 4 & M. fragilis & 53 & 11 & 64 & ++ & + \\
\hline 5 & L. conchilega & 78 & 0.4 & 78 & ++ & o \\
\hline 6 & $T$ marioni & 55 & 0.7 & 56 & ++ & o \\
\hline 7 & A. alba & 16 & 14 & 30 & + & + \\
\hline 8 & A brevicornis & 34 & 21 & 55 & ++ & + \\
\hline 9 & T. flexuosa & 24 & 11 & 33 & ++ & + \\
\hline 10 & S. filicornis & 20 & 15 & 35 & + & + \\
\hline 11 & Polycirrus sp. & 30 & 18 & 48 & ++ & + \\
\hline 12 & A. marina & 35 & 12 & 47 & ++ & + \\
\hline 13 & C. oerstedii & 53 & 0.7 & 54 & ++ & o \\
\hline 14 & N. latericeus & 51 & 27 & 78 & ++ & + \\
\hline 15 & C. capitata & 11 & 15 & 26 & + & + \\
\hline 16 & L. clypeata & 55 & 0.9 & 56 & ++ & o \\
\hline 17 & H. pectinata & 56 & 0.5 & 57 & ++ & 0 \\
\hline 18 & A. typica & 23 & 13 & 36 & ++ & + \\
\hline 19 & Oligochaetes & 26 & 12 & 38 & ++ & + \\
\hline 20 & P. strombi & 35 & 11 & 46 & ++ & + \\
\hline 21 & E. trunculata & 40 & 11 & 51 & ++ & + \\
\hline 22 & C. intermedius & 39 & 13 & 42 & ++ & + \\
\hline 23 & N. hombergii & 80 & 0.5 & 81 & ++ & $o$ \\
\hline 24 & C. sanguinea & 59 & 0.8 & 60 & ++ & o \\
\hline 25 & P. groënlandica & 15 & 12 & 27 & + & + \\
\hline 26 & H. lunulata & 78 & 0.3 & 78 & ++ & 0 \\
\hline 27 & E. longa & 72 & 0.4 & 72 & ++ & 0 \\
\hline 28 & L. incisa & 43 & 0.7 & 44 & ++ & 0 \\
\hline 29 & E. hebes & 42 & 0.9 & 43 & ++ & 0 \\
\hline 30 & O. albida & 28 & 15 & 43 & ++ & + \\
\hline
\end{tabular}

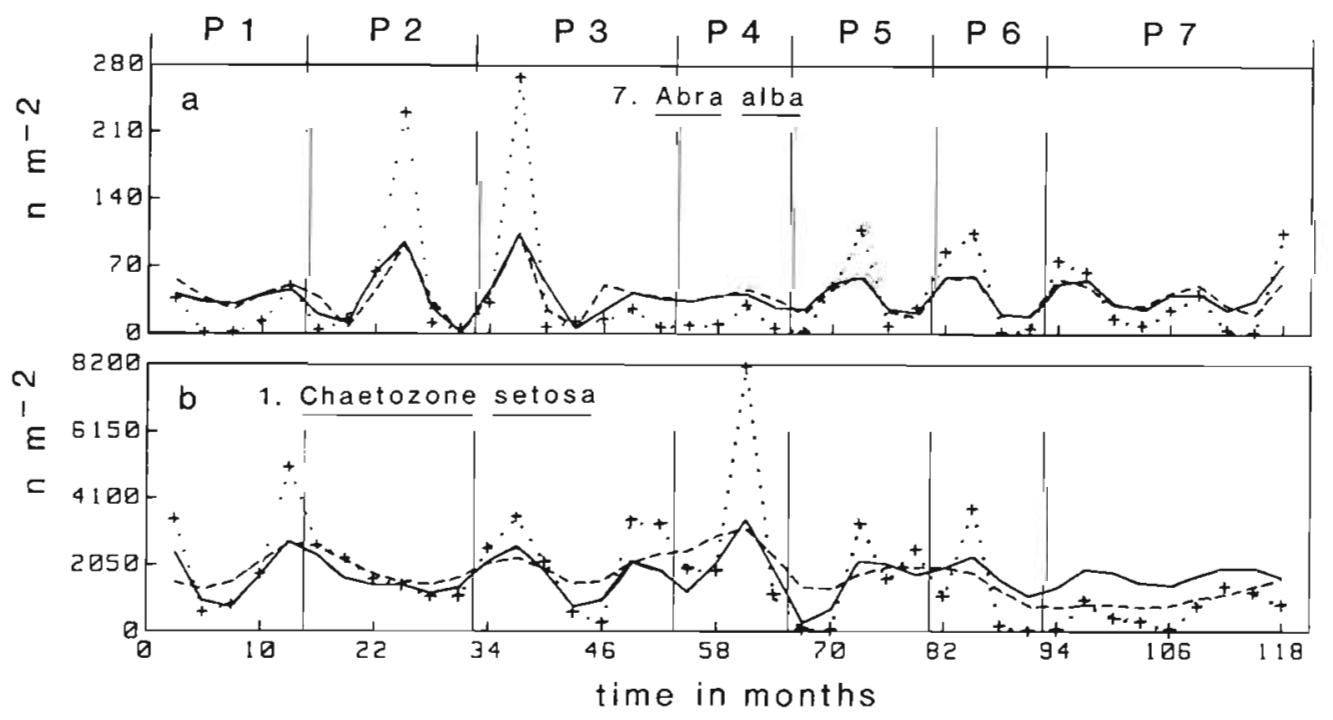

Fig. 1. (a) Abra alba; (b) Chaetozone setosa. Temporal variations in abundance for summer 1977 (Month 1) to spring 1987 (Month 118). $(+\cdots+)$ Initial data; $(-$ general trend; (--) seasonal trend; P 1 Period 1 etc. 

vicornis; (b) Melinna palmata; (c) Polycirrus sp. Temporal variations in abundance for summer 1977 (Month 1) to spring 1987 (Month 118). (+ $+\cdots+$ ) Initial data $(-)$ general trend; (--) seasonal trend P 1: Period 1 etc.
Fig. 2. (a) Ampelisca bre-
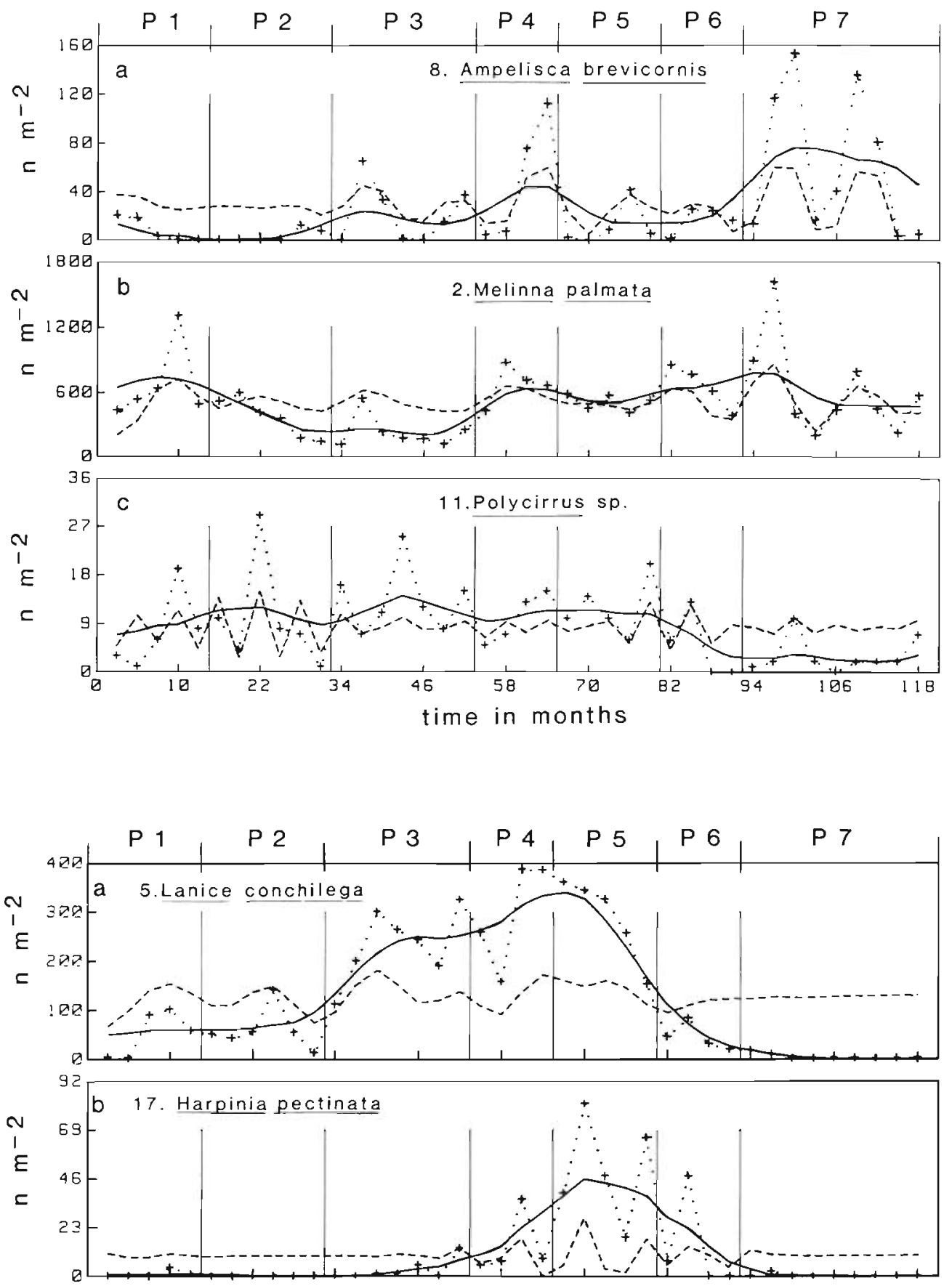

Fig. 3. (a) Lanice conchilega; (b) Harpinia pectinata, (c) Tharyx marioni. Temporal variations in abundance for summer 1977 (Month 1) to spring 1987 (Month 118). $(+\cdots+)$ Initial data; (-) general trend; (--) seasonal trend; P 1 : Period 1 etc.

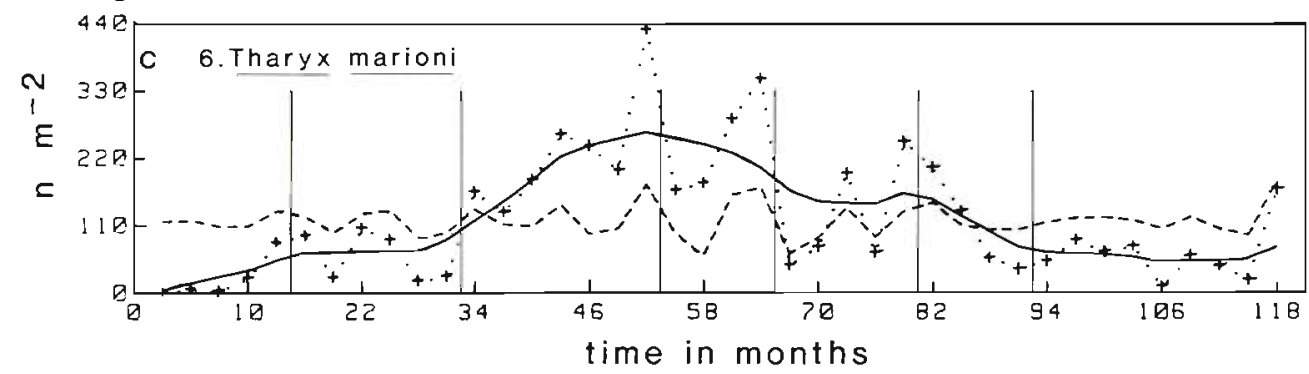


was strong. H. pectinata (Fig. 2b) was present during 4 annual cycles only. $T$. marioni (Fig. 2c) showed a smoothed trend with weak values at the extremities of the series. The seasonal variation was very irregular.

(3) Species with an explained percentage of variance dominant for the first $F V$, yet with a significant second FV $(++,+)$ : Melinna palmata, Mediomastus fragilis, Ampelisca brevicornis, Thyasira flexuosa, Polycirrus sp., Arenicola marina, Notomastus latericeus, Aora

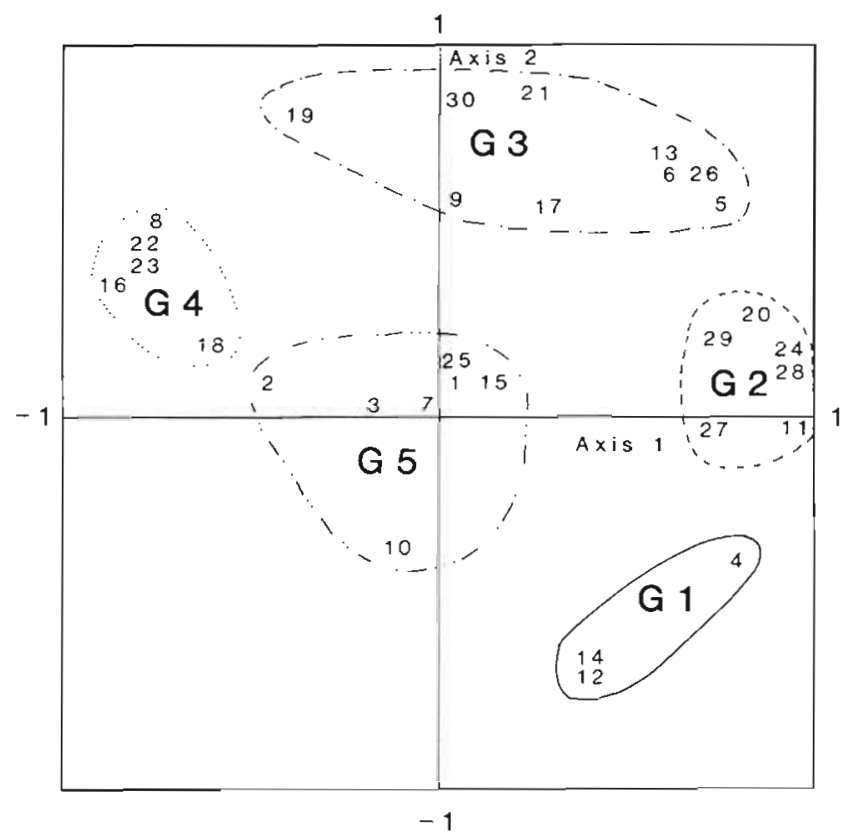

Fig. 4. Ordination of the 30 species in the plane of the first 2 components with identification of 5 groups by the Lance \& Williams (1967) clustering method. 1, 2 . .: Species Number; G 1: first group etc. typica, Oligochaetes, Phascolion strombi, Eudorella truncatula, Cheirocratus intermedius, Ophiura albida. Non-random variations were added to the trend: annual cycle $(4,8,12,14,18,20,21,22)$, fluctuations longer than 1 yr $(2,9,30)$ or shorter $(11,19)$. A. brevicornis (Fig. 3a) showed an increasing trend with an oscillation period of about $2 \mathrm{yr}$. The seasonal cycle was regular except for the first 2 yг. M. palmata (Fig. 3b) presented a large periodic tendency $(8 \mathrm{yr})$ with fluctuations of $18 \mathrm{mo}$. Polycirrus sp. (Fig. 3c) had a trend with an oscillation around 2 yr until it progressively disappeared during the last 3 yr. The annual cycle was completely hidden.

\section{Long-term changes in the benthic community}

Ordination of species starting from the trends

PCA of the correlation matrix between the first FVs permits an ordination for the species and the observations. The first 2 principal axes represent $58 \%$ of the total variance. Fig. 4 shows their correlations with the 3 species. The hierarchical clustering method described by Lance $\&$ Williams (1967) (flexible group method on the euclidean distances with $\beta=-0.3$ ) allowed us to distinguish 5 species groups at the 0.6 level of similarity. Starting clockwise from the first group, the gradient of abundance variation tends towards an inversion: Fig. 5 shows a pattern variable for each group representing the average trend of the corresponding species. In order of abundance, the first 4 groups have weak mean abundances whereas Group 5 shows a greater mean abundance.

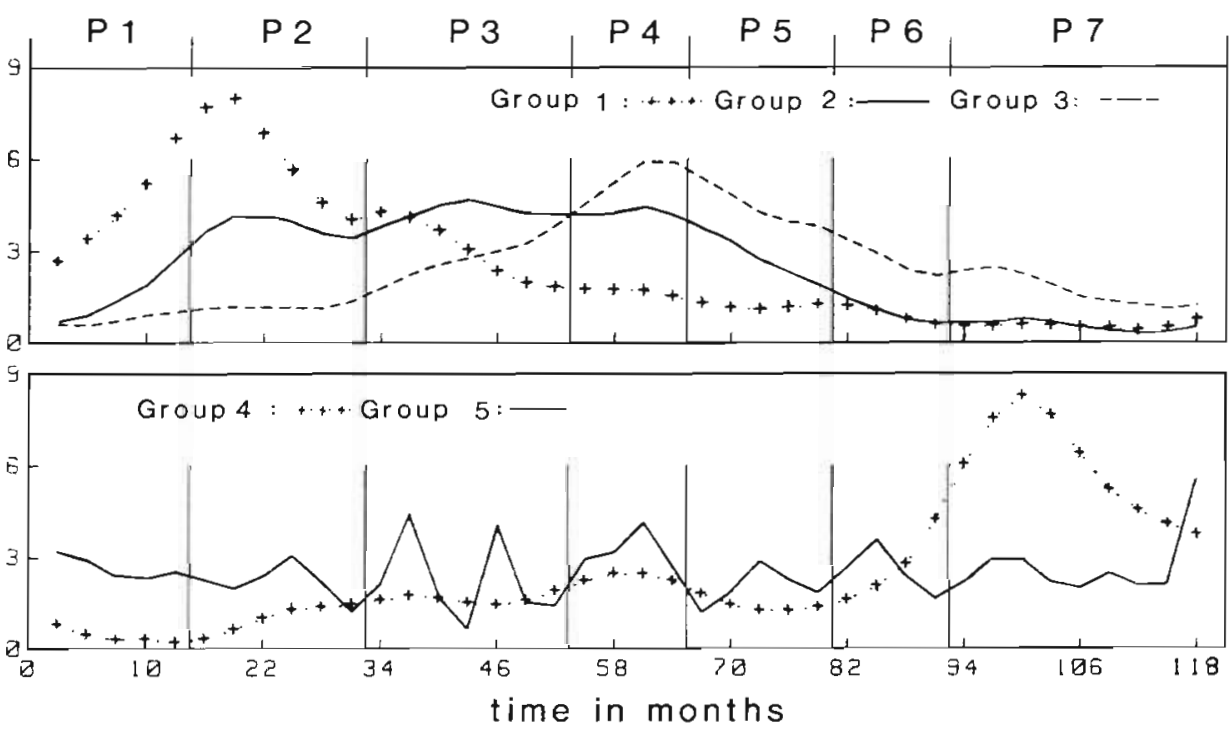

Fig. 5. Profiles of the 5 different groups of species defined by the Lance \& Williams (1967) hierarchical clustering method. The $y$-axis gives the cumulative percentage of the trend values divided by the number of species in the considered group $(x$ 100) 
For the first group $(12,14$ and 4$)$ the trend was strong during the first $3 \mathrm{yr}$, but after the 4 th year the species progressively vanished. The second group $(27,29,20$, 24, 28 and 11) presented an increasing trend until the 4 th year. In this case, the population disappeared after the 8 th year. The third group $(5,26,6,13,17,21,9,30$ and 19) had an almost symmetrical bell shape. Weak values were limited to the annual cycles at the extremities of the series. The fourth group $(23,8,22,16$ and 18) showed an almost continously increasing trend until the 8th year; afterwards the abundances presented a much stronger decreasing gradient. The fifth group $(1,2,3,7,10,15$ and 25) was characterised by a merely stationary variation.

\section{Order of observations in factorial space}

Fig. 6 shows the ordination of the 40 observations in the plane of the first 2 components which represent $58 \%$ of the total variance. The general aspect of the curve defined by connecting the successive observations looks like those obtained in a previous work (Dauvin \& Ibanez 1986). Again one finds a Guttman effect: the population structure tended towards a return to the initial situation. Seven groups of successive related observations had been identified by the hierarchical clustering method described by Lance \& Williams (1967) (flexible group method with $\beta$ : -0.3) at the $85 \%$ level of similarity.

Period 1: from Observation 1 (summer 1977) to 5 (summer 1978). This period showed a strong increase in the abundance of the species of the first group (see Fig. 5).

Period 2: from Observation 6 (autumn 1978) to 11 (winter 1980). This interval was characterised by the beginning of the gradient of Species Groups 2, 3 and 4 and by the inversion of the trend for the first group.

Period 3: from Observation 12 (spring 1980) to 18 (autumn 1981). This period corresponded to the maximum for the second group and a horizontal slope for the fourth group

Period 4: from Observation 19 (winter 1982) to 22 (autumn 1982). This was the time of maximum abundance for the third group and, globally, the maximum of divergence with respect to the initial situation.

Period 5: from Observation 23 (winter 1983) to 27 (winter 1984). During this interval the number of species of Groups 2 and 3 decreased and the population of the first group disappeared.

Period 6: from Observation 28 (spring 1984) to 31 (winter 1985). It marked the beginning of the strong increasing trend of the species of the fourth group and the continuation of the decreasing trend in the second and third groups.

Period 7: from Observation 32 (spring 1985) to 40 (spring 1987). These $2 \mathrm{yr}$ corresponded to the highest abundances for the species of the fourth group, whereas the abundance for the first 3 groups was strongly decreasing or absent.

\section{Abundance Biomass Comparison}

Fig. 7 shows the $A B C$ for the summer and winter situations during the $10 \mathrm{yr}$ of observations. As in the classification of Warwick (1986) and Warwick et al. (1987), the diagrams were placed in 3 groups: C, climax state, unpolluted conditions (with the biomass curve entirely above the abundance curve); I, inter-
Fig. 6. Ordination of the 40 observations in the plane of the first 2 components with identification of the 7 periods by the Lance \& Williams (1967) clustering method; P 1: Period 1 etc.

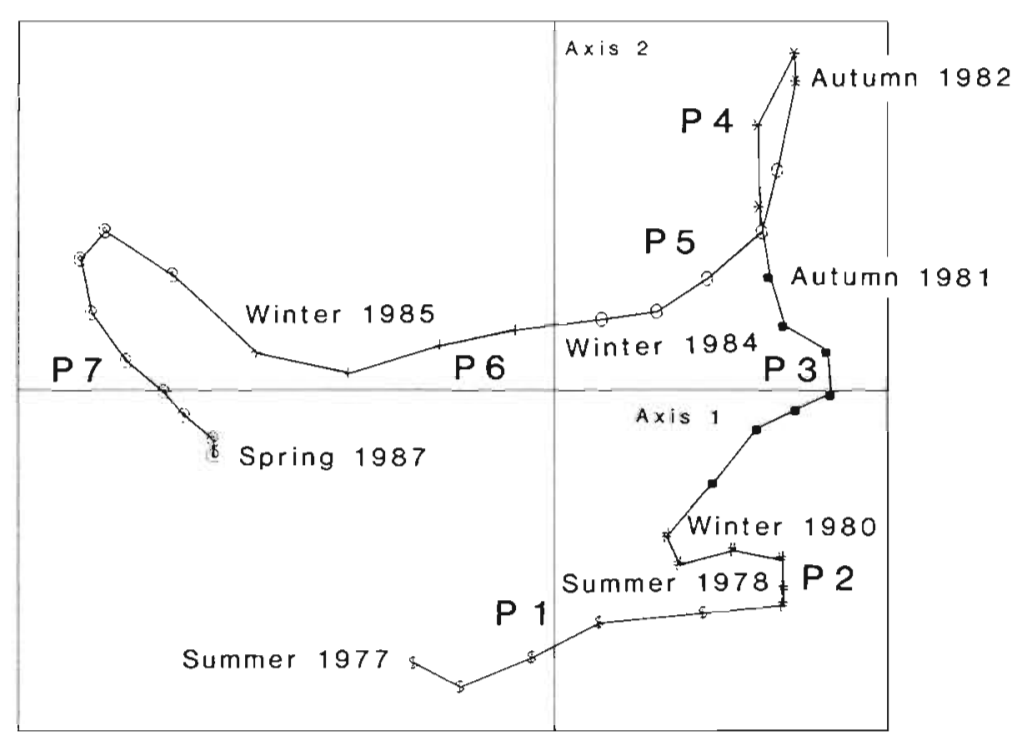



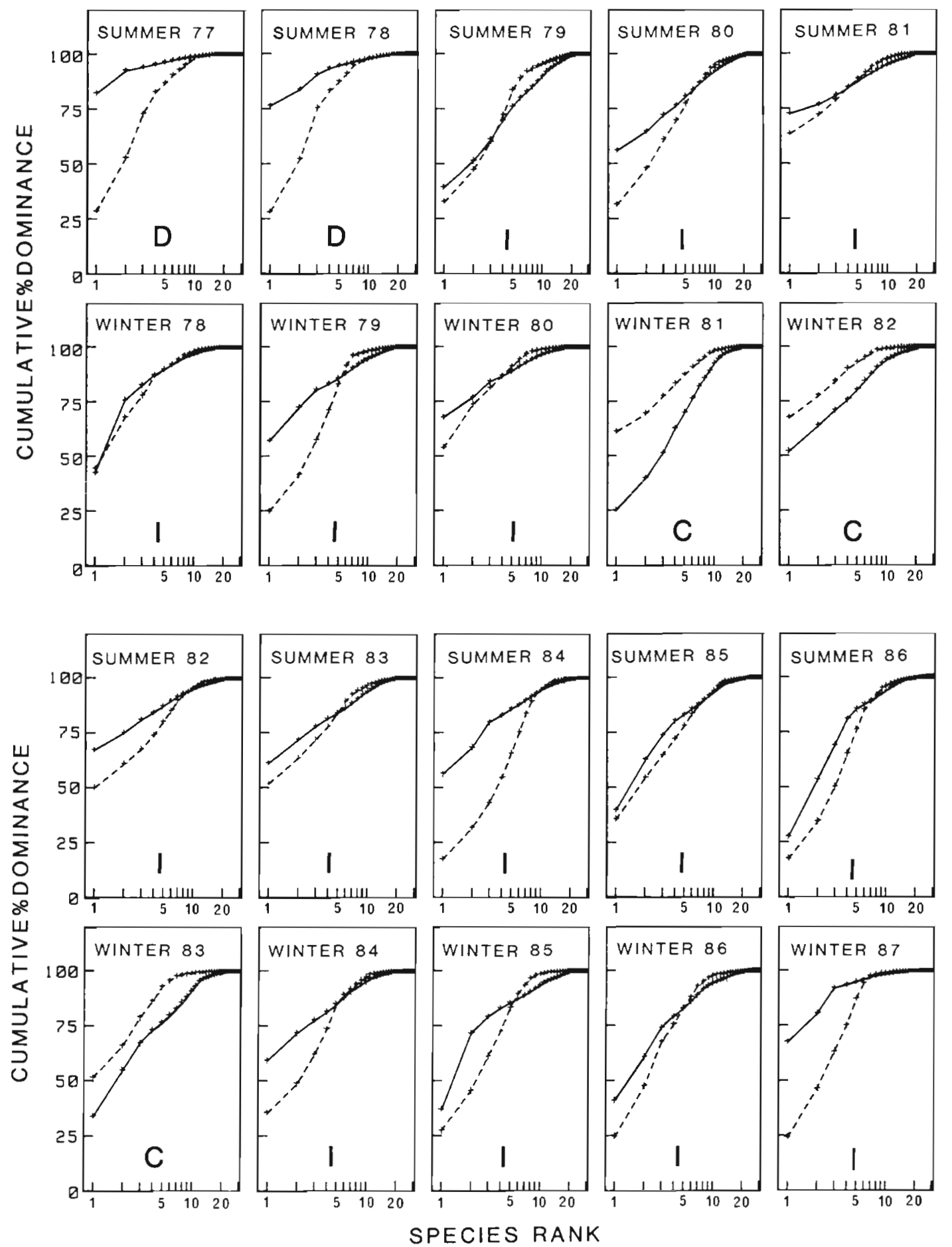

Fig. 7. Combined $k$-dominance curves for species biomass (dashed lines) and species abundance (continuous lines) for summer and winter 1977 to $1987 \mathrm{D}$ : disturbed conditions; I: intermediate state, C: climax state

mediate successional stage (with the abundance and biomass curves crossing one or more times); D, disturbed conditions, the benthic communities became increasingly dominated numerically by one or a few very small species (the number curves were above the biomass curves throughout their length). Two principal phenomena occurred. First there was an annual change in the $k$-dominance curves. The summer profiles were characteristic of a disturbed situation or intermediate stage while the winter profiles were 
Fig. 8. Combined $k$-dominance curves for species biomass (dashed lines) and species abundance (continuous lines) for the 7 successive periods. D: disturbed conditions; I: in-

termediate state; $\mathrm{C}$ : climax state

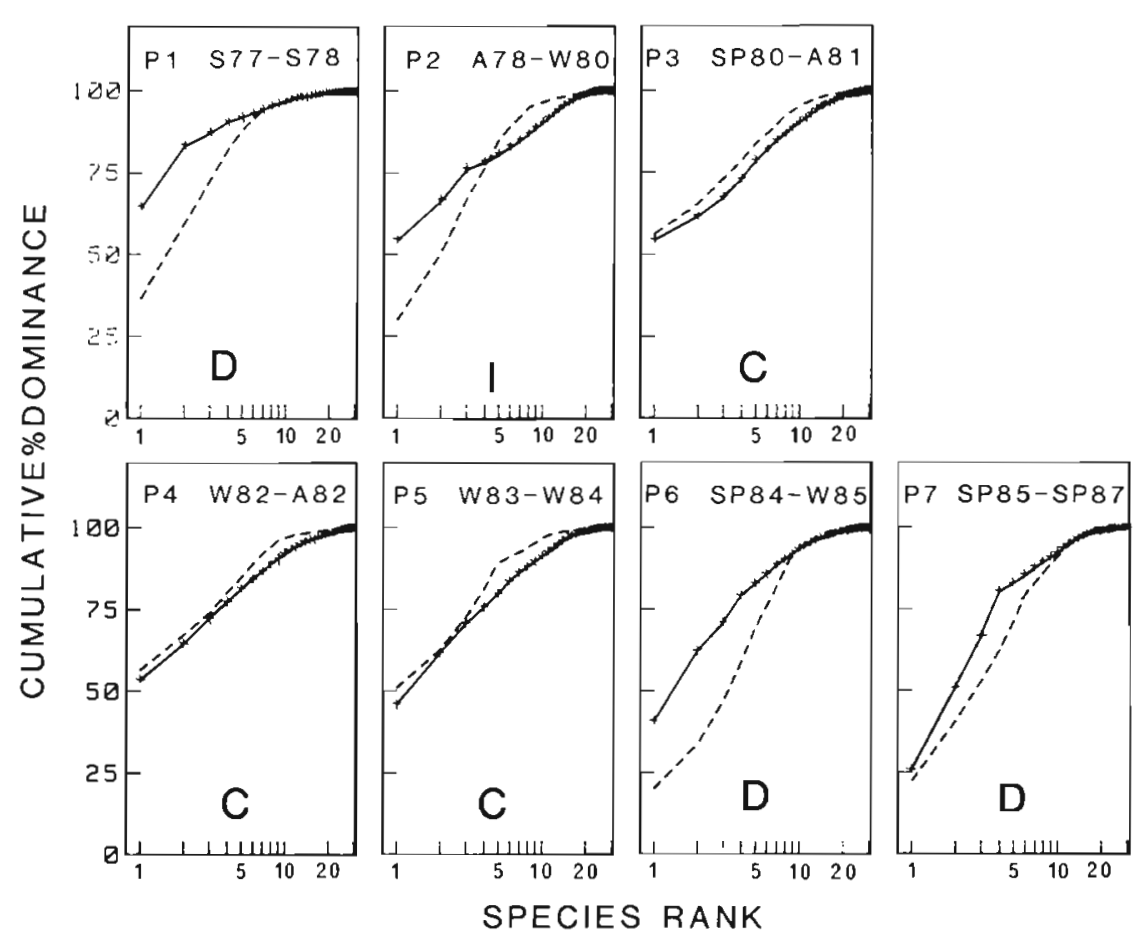

those of an intermediate climax state. The annual recruitment in spring and summer with many young individuals produced a rejuvenation of the community. Mortality was generally high during autumn and winter so the structure of the community changed to a more mature state. Secondly there was a long-term change in the $k$-dominance curves. The summers of 1977 and 1978 were characteristic of a disturbed situation, after which all the summer situations exhibited intermediate states. Winters 1978 to 1980 presented intermediate states, thereafter winters 1981 to 1983 corresponded to a climax state. Finally, during the 4 last winters the community again showed the intermediate situation.

Fig. 8 summarises the $k$-dominance curves for the 7 periods identified by the hierarchichal clustering. P1 showed a disturbed state, P2 an intermediate state, P3 to P5 a mature state and finally P6 and P7 a disturbed situation. Consequently the long-term changes in the community presented 3 states: first a disturbed state, which changes to a climax state, and then returns to a disturbed situation. This was in agreement with the PCA result: after $10 \mathrm{yr}$, the population structure tended towards a return to the initial situation. Table 4 shows the density and biomass dominances for the 10 first species ranked by biological index. The polychaete Lanice conchilega showed a high biomass dominance during P3 to P5 when the community was at a mature state. During the other periods the biomass dominance was distributed more uniformly between the species while Chaetozone setosa dominated numerically.

\section{Species classification based on seasonal variations}

Table 4 shows the seasons of the maxima for the 10 annual cycles. They were found by considering the main peaks of the second FV. Their total number and their frequency were indicated following the seasons. The species classification based on the relative importance between the first $2 \mathrm{FVs}$ was also derived.

A first operation consisted in grouping the species having less than 8 peaks (upper part of Table 4 ) or more than 12 peaks (lower part of Table 4). The first group could however present few seasonal cycles. The dominant species Chaetozone setosa presented a trend following the seasonal variation with some peaks in summer and autumn with a fluctuating intensity. Ophiura albida also had 4 seasonal maxima in summer. Lanice conchilega showed regular peaks in autumn in the 1981-1983 period of maximum abundance, and another 3 peaks in summer, but the association $(++, 0)$ showed that only the general trends show the correct changes in this species. Thyasira flexuosa showed some peaks in autumn; the association $(++,+)$ intensified this regularity. Eteone longa and Exogone hebes were rare or absent at the beginning or at the end of the observations. They, however, presented peaks in autumn from 1979 to 1983. Melinna palmata had peaks in spring and in summer; the association $(++,+)$ showed that this variability is not accidental. Four species (lower part of Table 4), Polycirrus sp., Clymene oerstedii, Capitella capitata, and Oligochaetes, presented more than 12 peaks and consequently showed 
Table 4. Seasons corresponding to the annual maxima of the 30 species for the $10 \mathrm{yr}$; number of peaks; report of relative dominance between the general trend (FV1) and seasonal vanation (FV2); number of peaks for each season and season of the greatest number of maxima. S: summer; A: autumn; W: winter; P: spring; I: irregular

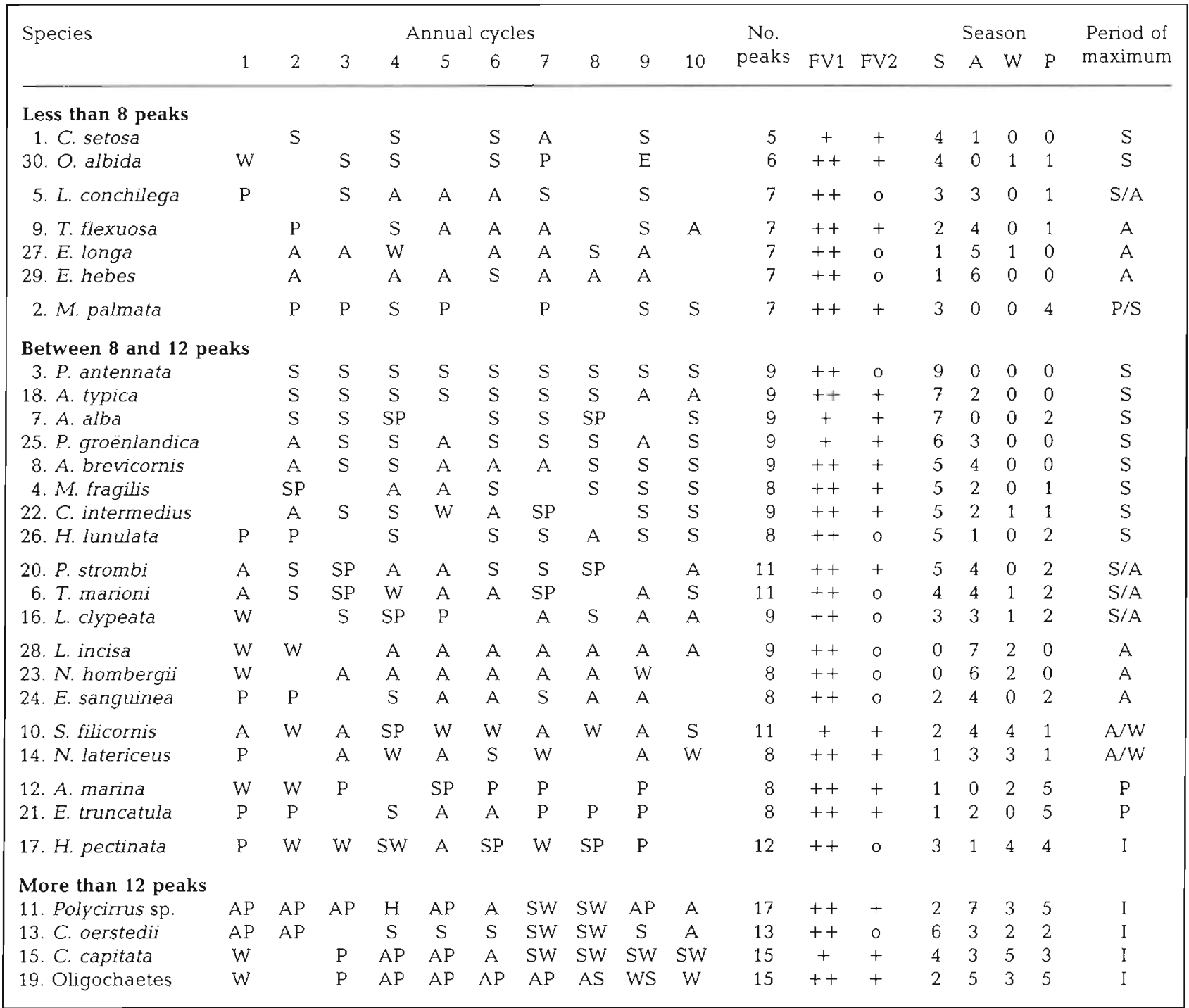

an irregular pattern of succession. The changes were rapid and consisted of different temporal scales.

The 19 other species had between 8 and 12 peaks and show, for the greatest part, a regular cycle. We could recognize 6 groups of species:

Group 1: 8 species peak preferentially in summer, Polydora antennata, Aora typica, Abra alba, Phyllodoce groënlandica, Ampelisca brevicornis, Mediomastus fragilis, Cheirocratus intermedius and Harmothoe lunulata. P. antennata and A. typica were typical of this group. Among these species, the seasonal trend $(+,+)$ was important for $A$. alba und $P$. groenlandica. The association $(++, 0)$ for $P$. antennata and $H$. Iunulata indicated that the amplitude of the maximum was variable from year to year. Two species, $P$. groënlandica and A. brevicornis, could also have peaks in autumn in relation to a delay of recruitment in some years.

Group 2: Three species, Phascolion strombi, Tharyx marioni and Leiochone clypeata, had peaks in summer or in autumn. T. marioni and $L$. clypeata $(++, 0)$ displayed a seasonal variation in addition to the general trend and $P$. strombi $(++,+)$ showed the greatest regular seasonal variations.

Group 3: Leucothoe incisa, Nephtys hombergii and Eulalia sanguinea had peaks particularly in autumn and secondarily in winter, but $E$. sanguiena also showed a peak in summer and in spring. The association $(++, 0)$ for these species showed that the second FV was conditioned by the general trend. 
Group 4: Spio filicornis and Notomastus latericeus had peaks in autumn or in winter. S. filicornis showed a typical seasonal variation $(+,+)$.

Group 5: Arenicola marina and Eudorella truncatula showed a maximum of peaks in spring; nevertheless the densities of this species were weak and the result must be confirmed.

Group 6: Harpinia pectinata $(++$, o) showed peaks without regular patterns; moreover the species was abundant only from 1981 to 1985 .

Among the 25 species having 5 to 11 peaks (Table 4), we totalled $42 \%$ of peaks in summer, $34 \%$ in autumn, $16 \%$ in spring and only $9 \%$ in winter. Therefore there was a concentration of maximal abundances in summer and in autumn and inversely a concentration of minimal abundances in winter. Ten species are summer species, 6 are autumnal species and 4 summer-autumnal species.

\section{Distogram of trophic groups}

Dissimilarity is calculated for observations separated by 3 to 57 mo with a constant scale of 3 mo (Fig. 9) For nil difference, the dissimilarity $\left(\bar{d}^{2}\right) y$-axis intercept is above zero; there is a residual variance between independent temporal replicates (Mackas 1984). Two types of variations can be distinguished.

The first type included the carnivore/omnivore group and the mixed group. They showed an annual change with parallel curves of density and biomass variations. The observations were more consistent among them- selves for an annual time scale (12 mo) than for short scale of 3 or 6 mo. On the other hand, there was an increase in the length of the cycle over the long term. In fact, the observations were more comparable among themselves for an annual scale compared to a longer time scale $(24,36,48 \mathrm{mo})$. This result was particularly marked in the case of the abundance of the carnivore/ omnivore group.

The second type corresponded to the subsurfacedeposit feeder group. Firstly, the density dissimilarity showed an increasing trend without any annual cycle. The function has a parabolic form near the theoretical dissimilarity correlogram for a variable affected by turbulent diffusion (Mackas 1984). Secondly, the biomass dissimilarity was nil: there was neither annual variation nor long-term change.

\section{DISCUSSION}

\section{Long-term changes of benthic community}

This community is located near the outflow of the River Morlaix, and exists in an environment rich in nutrients. Populations of polychaetes are predominant; the dominant species, Chaetozone setosa, was recognized as an opportunist species by Hily (1984) in a similar community in the Bay of Brest (W Brittany). Melinna palmata, Notomastus latericeus, Polydora antennata and Spio filicornis are also tolerant to an excess of organic matter, whereas Nephtys hombergii, Thyasira flexuosa and Albra alba are unaffected by an
Fig. 9. Distogram for biomass and density for the 3 trophic groups. $\mathrm{C}+\mathrm{O}$ : carnivore/omnivore group: $M$ : mixed group; SSD: subsurface-deposit feeder group. $\mathrm{D}$ : density; $\mathrm{B}$ : biomass

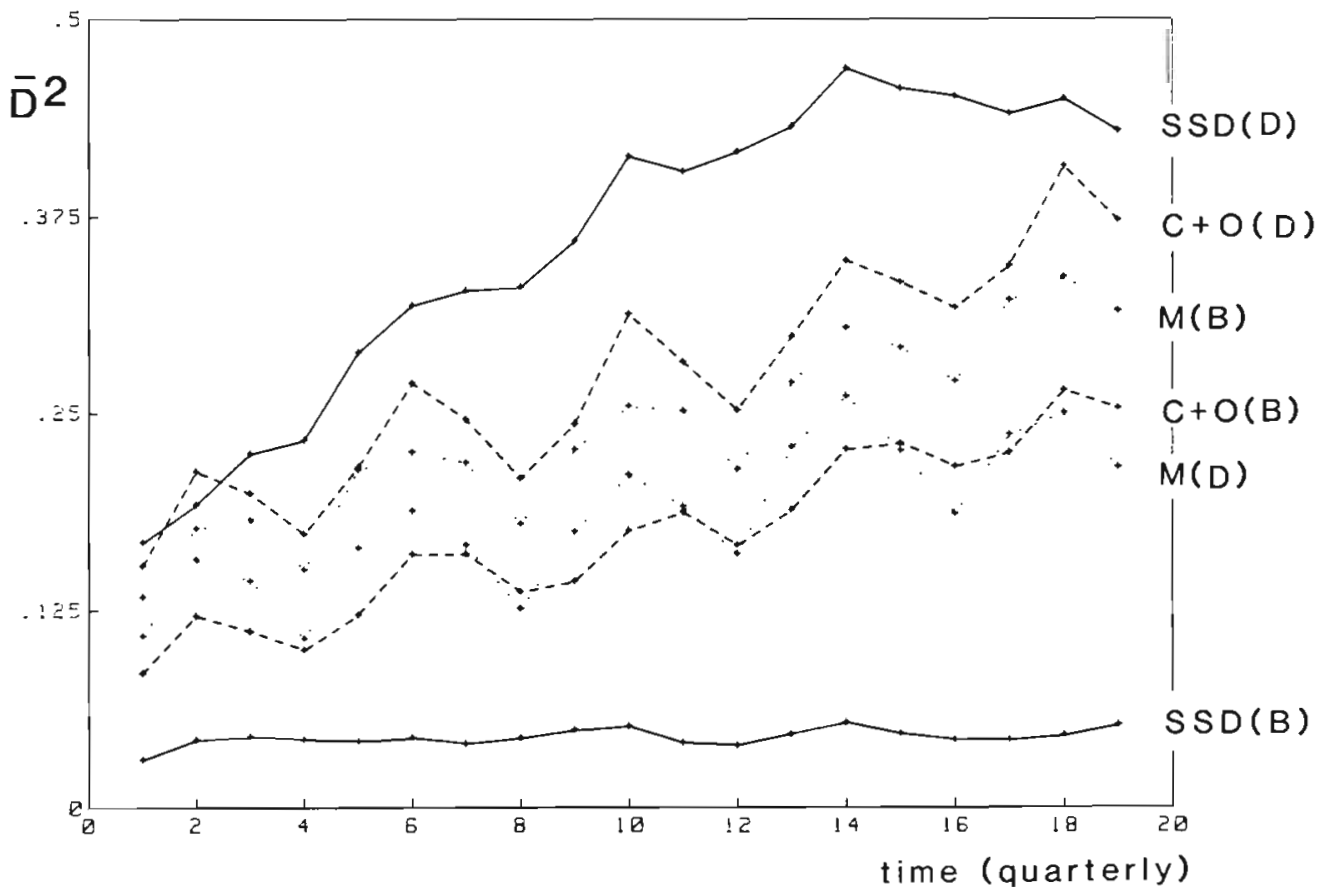


Table 5. Ten first species in density and in biomass ranking by biological index of Sanders (1960) with indication of their dominance. (Err polychaetes errant polychaetes; sed. polychaetes: sedentary polychaetes)

\begin{tabular}{|c|c|c|c|c|c|c|c|c|}
\hline & \multicolumn{4}{|c|}{ Period 1: summer 1977-summer 1978} & \multicolumn{4}{|c|}{ Period 2: autumn 1978-winter 1980} \\
\hline & Density & $\%$ & Biomass & $\%$ & Density & $\%$ & Biomass & $\%$ \\
\hline 1 & C. setosa & 57.5 & M. palmata & 37.5 & C. setosa & 55.7 & N. latericeus & 31.5 \\
\hline 2 & M. palmata & 24.9 & N. hombergii & 13.3 & M. palmata & 11.5 & L. conchilega & 19.6 \\
\hline 3 & L. latericeus & 3.8 & N. latericeus & 16.0 & M. fragilis & 8.5 & M. palmata & 16.0 \\
\hline 4 & M. fragilis & 2.9 & C. setosa & 8.7 & N. latericeus & 2.3 & N. hombergii & 9.6 \\
\hline 5 & C. oerstedii & 1.4 & L. conchilega & 10.0 & C. oerstedii & 2.4 & C. oerstedii & 9.2 \\
\hline 6 & $N$. hombergii & 1.4 & C. oerstedii & 3.6 & L. conchilega & 2.0 & C. setosa & 3.0 \\
\hline 7 & S. filicornis & 2.1 & Pagurus spp. & 1.3 & T marioni & 1.9 & Pagurus spp. & 4.3 \\
\hline 8 & L. conchilega & 1.7 & Other decapods & 0.3 & $T$ flexuosa & 1.3 & Err. polychaetes & 0.8 \\
\hline 9 & P. antennata & 0.6 & $N$. reticulatus & 0.4 & E. sanguinea & 1.5 & M. fragilis & 0.7 \\
\hline \multirow[t]{3}{*}{10} & T. marioni & 0.5 & A. alba & 4.7 & E. longa & 1.4 & A. alba & 2.3 \\
\hline & \multicolumn{4}{|c|}{ Period 3: spring 1980-autumn 1981} & \multicolumn{4}{|c|}{ Period 4: winter 1982-autumn 1982} \\
\hline & Density & $\%$ & Biomass & $\%$ & Density & $\%$ & Biomass & $\%$ \\
\hline 1 & C. setosa & 49.1 & L. conchilega & 56.0 & C. setosa & 46.8 & L. conchilega & 55.2 \\
\hline 2 & M. fragilis & 8.2 & N. hombergü & 9.4 & M. palmata & 13.5 & N. hombergii & 10.5 \\
\hline 3 & L. conchilega & 6.8 & C. oerstedii & 7.8 & L. conchilega & 5.9 & M. palmata & 6.9 \\
\hline 4 & $T$ marioni & 6.7 & N. latericeus & 5.9 & T. marioni & 5.0 & C. oerstedii & 6.6 \\
\hline 5 & M. palmata & 5.7 & M. palmata & 5.3 & M. fragilis & 3.5 & L. Latericeus & 4.3 \\
\hline 6 & N. hombergï & 4.0 & Pagurus spp. & 2.9 & N. hombergii & 3.2 & Pagurus spp. & 4.0 \\
\hline 7 & E. sanguinea & 1.5 & C. setosa & 2.9 & C. oerstedii & 2.7 & C. setosa & 2.4 \\
\hline 8 & C. oerstedii & 2.2 & Polycirrus sp. & 1.5 & P. antennata & 7.2 & H. lunulata & 2.0 \\
\hline 9 & $N$. latericeus & 1.9 & H. lunulata & 1.4 & E. sanguinea & 1.9 & P. antennata & 4.0 \\
\hline \multirow[t]{3}{*}{10} & E. longa & 1.5 & $N$ reticulatus & 0.6 & H. Iunulata & 1.4 & Err. polychaetes & 0.9 \\
\hline & \multicolumn{4}{|c|}{ Period 5: winter 1983-winter 1984} & \multicolumn{4}{|c|}{ Period 6: spring 1984-winter 1985} \\
\hline & Density & $\%$ & Biomass & $\%$ & Density & $\%$ & Biomass & $\%$ \\
\hline 1 & M. palmata & 19.2 & L. conchilega & 49.5 & M. palmata & 29.5 & L. conchilega & 20.9 \\
\hline 2 & L. conchilega & 11.8 & M. palmata & 11.9 & N. hombergii & 17.4 & M. palmata & 14.4 \\
\hline 3 & C. oerstedii & 4.9 & N. hombergii & 10.3 & T. marioni & 4.2 & N. hombergii & 17.2 \\
\hline 4 & N. hombergii & 6.4 & C. oerstedii & 9.0 & C. setosa & 25.7 & C. oerstedii & 13.0 \\
\hline 5 & C. setosa & 35.1 & N. latericeus & 8.5 & C. oerstedii & 4.1 & Pagurus spp. & 3.5 \\
\hline 6 & T. marioni & 3.7 & H. Iunulata & 1.8 & $M$. fragilis & 2.3 & N. latericeus & 7.1 \\
\hline 7 & M. fragilis & 2.8 & N. reticulatus & 1.7 & L. conchilega & 1.7 & $N$. reticulatus & 2.7 \\
\hline 8 & H. lunulata & 2.3 & Pagurus spp. & 1.2 & P. antennata & 4.9 & Sed. polychaetes & 1.8 \\
\hline 9 & E. sanguinea & 2.3 & Err. polychaetes & 0.9 & T flexuosa & 1.1 & P. antennata & 3.5 \\
\hline \multirow[t]{3}{*}{10} & H. pectinata & 2.0 & Polycirrus sp. & 0.6 & P. groënlandica & 1.0 & H. lunulata & 1.1 \\
\hline & \multicolumn{4}{|c|}{ Period 7 spring $1985-$ spring 1987} & & & & \\
\hline & Density & $\%$ & Biomass & $\%$ & & & & \\
\hline 1 & M. palmata & 25.1 & N. hombergij & 24.2 & & & & \\
\hline 2 & N. hombergii & 19.4 & M. palmata & 18.2 & & & & \\
\hline 3 & C. setosa & 25.7 & N latericeus & 13.1 & & & & \\
\hline 4 & P. antennata & 10.5 & C. oerstedii & 8.4 & & & & \\
\hline 5 & $T$ marioni & 2.6 & Pagurus spp. & 10.0 & & & & \\
\hline 6 & C. oerstedii & 2.4 & P. antennata & 5.7 & & & & \\
\hline 7 & A. brevicornis & 2.5 & Sed polychaetes & 2.1 & & & & \\
\hline 8 & I flexuosa & 1.4 & $N$. reticulatus & 2.4 & & & & \\
\hline 9 & M. fragilis & 1.1 & C. setosa & 3.9 & & & & \\
\hline 10 & N. latericeus & 1.2 & L. conchilega & 2.3 & & & & \\
\hline
\end{tabular}


excess of organic matter. The 'Amoco Cadiz' oil spill modified this benthic ecosystem by introducing a high level of hydrocarbons in the sediment, from spring 1978 to spring 1980 (Dauvin 1982). After the primary phase had induced heavy mortalities, the second phase of pollution was characterized by an excess of organic matter in the benthic communities (Dauvin 1982, 1984).

The PCA on the general trends of the descriptors shows that the muddy fine-sand community at 'Rivière de Morlaix' station presents progressive changes over time. The observations of the 2 first periods $\mathrm{P} 1$ and $\mathrm{P} 2$ (summer 1977 to winter 1980) are close together in the factorial space. During the first annual cycle after the oil spill, some species were found to be very abundant, like the opportunistic polychaete Chaetozone setosa (which was abundant before pollution) and other polychaetes Mediomastus fragilis and Tharyx marioni (which are rare in natural conditions in the Bay of Morlaix). From the third period, P3, the changes increase progressively. The maximum divergence is reached at the 4 th period, P4. These 2 periods, P3 and P4, are characterised by the gradual settling out of Lanice conchilega (species of Group 3). P5 corresponds to the regression of the facies of $L$. conchilega. During the 6 th period a decrease of species in Groups 2 and 3 occurred, and the beginning of an increase of species of Group 4. The last period, P7, is a return to the initial situation. The amphipods Ampelisca brevicornis, Aora typica and Cheirocratus intermedius of Group 4 recolonised the community, while Melinna palmata increased progressively.

This succession seems similar to those described by Pearson \& Rosenberg (1978) and Hily (1984) in cases of organic pollution. This study shows that recovery took $10 \mathrm{yr}_{i}$ nevertheless the process is not completely reversible.

With the $A B C$ method of Warwick (1986) successional phenomena are also recognisable: first a disturbed or intermediate state ( $\mathrm{P} 1$ and $\mathrm{P} 2)$, then a mature state during the facies of Lanice conchilega and a return to the disturbed state at the end of the observations (P6 and P7). This method has been also applied to the 'Pierre Noire' data. In natural conditions Ampelisca species were numerically dominant and their populations were destroyed by the 'Amoco Cadiz' oil spill. In these conditions the $A B C$ method shows a disturbed state during the dominance by Ampelisca and a mature state after the 'Amoco Cadiz' oil spill. Therefore, the $\mathrm{ABC}$ method may be used in certain cases to distinguish successive steps after pollution, but in the 'Pierre Noire' case it was of no use. In this community other synthetic methods such as log-normal diagrams were also ill-adapted to expose perturbations (Dauvin 1984).

Table 5 lists the first 10 species ranked in decreasing order of density or biomass according to Sanders' index (1960). It mainly shows the abundance and decalcified dry weight decrease for Melinna palmata from P2 to P5, the opposite behaviour for Lanice conchilega from P1 to P5 followed by extinction, the numerical increase of Mediomastus fragilis (opportunist polychaete) during P2 and P3 and the high importance of Nephtys hombergii during P6 and P7.

The appearance of a facies of Lanice conchilega in spring 1980 is coincident with the period when the degree of pollution first fell below the significant threshold $\left(50 \mu \mathrm{g} \mathrm{g}^{-1}\right)$.

The unpolluted sediments probably permitted the recruitment of sensitive species such as Clymene oerstedii, Lanice conchilega and the peracarids (Group 3: Harpinia pectinata, Eudorella trunculata; Group 4: Ampelisca brevicornis, Aora typica and Cheirocratus intermedius). However, the degree of pollution of sediments does not account for all the population changes.

Besides the species abundances and biomasses, we collected data on the sediment granulometry and on hydrological parameters. The median grain size and the percentage of particles smaller than $63 \mu \mathrm{m}$ did not vary significantly from one period to the next (Table 6): medians ranged from $0.088 \pm 0.007$ to $0.101 \pm 0.014$ $\mu \mathrm{m}$ and percentages of small particles were between $28.49 \pm 4.51$ and $30.51 \pm 4.58$.

Mean minimal temperatures in winter increased from P1 to P4 $\left(8.44\right.$ to $9.70^{\circ} \mathrm{C}$ ). Then it decreased sharply during the period P5 $\left(7.58^{\circ} \mathrm{C}\right)$, increased in P6 $\left(8.41^{\circ} \mathrm{C}\right.$ ) and reached a minimum in $\mathrm{P} 7$ (hard winter of $1986: 5.8^{\circ} \mathrm{C}$ ). The mean of maximal temperatures in summer had its peak during $\mathrm{P} 4\left(6.68^{\circ} \mathrm{C}\right)$.

Changes in the population could therefore, be of climatic origin: there were successive mild winters from 1978 to 1982, then severe winters from 1983 to 1987. Several authors (Gray \& Christie 1983, Princz et al. 1983, Rees et al. 1983, Buchanan \& Moore 1986a, b) have suggested climatic factors as an explanation for population changes. For instance, considering Lanice conchilega associated with a population of Abra alba in Liverpool Bay, UK, Rees et al. (1983) noticed a cycle of about 6 to $7 \mathrm{yr}$. This oscillation of the recruitment seemed to be synchronised with similar events occurring in a part of the North Sea. In the case of the Bay of Morlaix, observations over a longer time span are needed to test this hypothesis.

In summary, the principal chronological steps of the succession are (1) mortality of a few peracarid species after the initial stress and stimulation of opportunistic polychaetes abundant in the community in natural conditions; (2) colonization and disappearance of Lanice conchilega; and (3) re-establishment of the peracarid populations and return of the opportunistic polychaetedominated community pre 'Amoco Cadiz'. In temporal succession, it is always difficult to distinguish between fluctuations induced by external factors and real succes- 
Table 6. Characteristics of the granulometry and the hydrologic conditions during the 7 periods of succession of the community

\begin{tabular}{|c|c|c|c|c|}
\hline \multirow[t]{2}{*}{ Period } & \multicolumn{2}{|c|}{ Granulometry } & \multicolumn{2}{|c|}{ Hydrology (bottom layers) } \\
\hline & Median (km) & $\%<63 \mu \mathrm{m}$ & $\begin{array}{c}\text { Mean minimal } \\
\text { temp. }\left({ }^{\circ} \mathrm{C}\right)\end{array}$ & $\begin{array}{l}\text { Mean maximal } \\
\text { temp. }\left({ }^{\circ} \mathrm{C}\right)\end{array}$ \\
\hline P1 & $0.101 \pm 0.014$ & $28.49 \pm 4.51$ & 8.44 & 16.10 \\
\hline $\mathrm{P} 2$ & - & - & 8.90 & 16.10 \\
\hline P3 & - & - & 9.10 & 15.40 \\
\hline P4 & $0.096 \pm 0.013$ & $29.43 \pm 1.69$ & 9.70 & 16.90 \\
\hline P5 & $0.094 \pm 0.009$ & $28.59 \pm 6.69$ & 7.58 & 16.68 \\
\hline $\mathrm{P} 6$ & $0.088 \pm 0.007$ & $30.51 \pm 4.58$ & 8.41 & 15.90 \\
\hline P7 & $0.095 \pm 0.019$ & $29.66 \pm 8.27$ & 7.0 & 16.00 \\
\hline
\end{tabular}

sion corresponding to internal factors (Princz et al. 1983). It appears that the pollution and climatic changes induced fluctuations; but the fact that the community developed from disturbed to stable and to disturbed states may be due to an autogenic succession.

\section{Seasonal variations}

Taking into account the second FV representing the seasonal variation allows one to determine objectively the number of annual peaks of species distributions. The periods corresponding to the maximum abundances are summer and autumn, a consequence of increased recruitment in spring and summer (Dauvin 1984). In the Bay of Morlaix, recruitment is limited to a single, short time for most species. In the opposite case, when recruitment occurs in more than one phase or over a longer duration, it always occurs in spring or summer. Then, the densities vary at the same time in the annual cycle, with their maxima in summer or autumn and thereafter decreasing regularly.

However, at present only the macrobenthic phase is actually known, and the use of a sieve with smaller mesh size is needed in order to estimate the intensity and timing of the recruitment period. An increase in the densities observed on a $1 \mathrm{~mm}$ mesh at a particular time may be the result of a previous recruitment and, therefore, would represent a small percentage of the juveniles settled. However in North European seas, the macrobenthic populations generally show a regular seasonality (maxima at the end of summer and beginning of autumn and minima at the end of winter and beginning of spring) (Dauvin 1984). This seasonal variation appears to be a characteristic of temperate seas.

\section{Succession of trophic groups}

In a previous study (Dauvin \& Ibanez 1986), we emphasised 4 types of temporal changes for trophic groups in relation to their demographic strategy and their ability to reconstruct the community after the 'black tide'. In the case of 'the Morlaix River' the distograms show both the seasonality and the general trends of the trophic groups. An annual variation was observed for 2 of the 3 groups (mixed; carnivore/omnivore).

The magnitude of the dissimilarities between seasons is identical in both the densities and the biomasses; and it seems similar from one trophic group to another.

One of the most important results given by the distograms is to show the population changes at scales longer than 1 yr. Subsurface-deposit feeders show an extreme case of temporal change because their difference is always increasing with a maximum for time scales greater than $3 \mathrm{yr}$. In this group belong the most disturbed species which present the greatest ability to come back to the initial unpolluted stage: amphipods (Cheirocratus intermedius, Aora typica) and cumaceans (Eudorella truncatula). The reconstitution is progressive year after year.

Another typical case is the distogram of biomass of the subsurface-deposit feeders which seems stable at any scale. Most of the biomass in this group is accounted for by Clymene oerstedii and Notomastus latericeus with a few biomass changes. The quantity of the subsurface-deposit feeders is in fact maximal, and is only limited by the organic matter in the sediments that is directly assimilable by the macrobenthic species.

Finally, these results show the value of comparing temporal variations in both the abundances and biomasses. For some trophic groups, the strong differences between these parameters give rise to a more precise description of their pattern of ecological behaviour.

In conclusion, the muddy fine sand community of the Bay of Morlaix exhibits long-term changes in relation to the 'Amoco Cadiz' oil spill and climatic variations due to severe winters. The relationship between the pollution and the increase in opportunistic populations is evident. The mechanism of the colonization and the 
disappearance of Lanice conchilega is more difficult to interpret. The re-establishment of the pre-Amoco Cadiz' structure takes a long-time and justified a longterm survey of this benthic community after such a stress. Long-term series will permit one to distinguish between variability due to natural fluctuations, and to autogenic successions.

These data were analyzed by methods seldom used in benthos analysis. The generalization of these methods in benthic studies should allow the comparison in space and time of the scale of hydrographic factors for the observed phenomena.

Acknowledgements. This study was carried out under the program 'GRECO Manche du CNRS'. It is also a part of the research programs 'Amoco Cadiz' and 'Veille Ecologique', sponsored by the NOAA-CNEXO, the 'Ministère de l'Environnement et du Cadre de Vie' and the 'Région Bretagne'. The authors thank the crew of NO 'Mysis' for their valuable assistance in field work, $M$. Joncourt for her help in sorting the samples, $M$. Etienne for her help in information programming, B. Kloareg and J. C. Aldrich for help in correcting the English text and N. Guyard for typing the manuscript.

\section{LITERATURE CITED}

Beslier, A. (1981). Les hydrocarbures de l'Amoco Cadiz dans les sédiments subtidaux au nord de la Bretagne. Distribution et évolution. Thèse Doct. 3ème cycle, Univ. Caen

Buchanan, J. B., Moore, J. J. (1986a). Long-term studies at a benthic station off the coast of Northumberland. Hydrobiologia 142: 121-127

Buchanan, J. B., Moore, J. J. (1986b). A broad review of variability and persistence in the Northumberland benthic fauna - 1971-85. J. mar. biol. Ass. U. K. 66: 641-657

Cabioch, L., Dauvin, J.-C., Gentil, F. (1978). Preliminary observations on pollution of the sea bed and disturbance of sub-littoral communities in northern Brittany by oil from the Amoco Cadiz. Mar. Pollut. Bull. 9: 303-307

Cabioch, L., Dauvin, J.-C., Mora Bermudez, J., Rodriguez Babio, C. (1980). Effets de la marée noire de l'AmocoCadiz sur le benthos sublittoral du nord de la Bretagne. Helgoländer Meeresunters. 33: 192-208

Cabioch, L., Dauvin, J.-C., Retière, C., Rivain, V., Archambault, D. (1982). Evolution à long terme (1978-1981) de peuplements benthiques de fond sédimentaire de la région de Roscoff, perturbés par les hydrocarbures de l'AmocoCadiz. Neth. J. Sea Res. 16: 491-501

Colebrook, J. M. (1978). Continuous plankton records: zooplankton and environment, North-East Atlantic and North Sea 1948-1975. Oceanologica Acta 1: 9-23

Dauvin, J.-C. (1979). Recherches quantitatives sur le peuplement des sables fins de la Pierre Noire, baie de Morlaix et sur sa perturbation par les hydrocarbures de l'Amoco Cadiz. Thèse Doct. 3ème cycle, Univ. P. \& M. Curie, Paris

Dauvin, J.-C. (1982). Impact of Amoco Cadiz oil spill on the muddy fine sand Abra alba and Melinna palmata community from the bay of Morlaix. Estuar. coast. Shelf Sci. 14 $517-531$

Dauvin, J.-C. (1984). Dynamique d'écosystèmes macrobenthiques des fonds sédimentaires de la baie de Morlaix et leur perturbation par les hydrocarbures de l'Amoco Cadiz. Thèse Doct. Etat, Sci. Nat,, Univ. P. \& M. Curie, Paris

Dauvin, J.-C., Ibanez, F. (1986). Variations à long-terme (1977-1985) du peuplement des sables fins de la Pierre Noire (baie de Morlaix, Manche occidentale): analyse statistique de l'évolution structurale. Hydrobiologia 142: $171-186$

Gray, J. S., Christie, H. (1983). Predicting long-term changes in marine benthic communities. Mar. Ecol. Prog. Ser. 13: $87-94$

Hily, C. (1984), Variabilité de la macrofaune benthique dans les milieux hypertrophiques de la rade de Brest. Thèse Doct. Etat, Sci. Nat, Univ. Brest

Ibanez, F. (1983). Optimisation de la représentation des séries chronologiques planctoniques multivariables. Rapp. comm. int. Mer Médit. 28: 113-115

Ibanez, F., Boucher, J. (1987). Anisotrophie des populations zooplanctoniques dans la zone frontale de la mer Ligure. Oceanologica Acta 10: 205-216

Kendall, M. (1973). Time-series. Griffin, London

Lance, G. N., Williams, W. T. (1967). A general theory of classificatory sorting strategies. I. Hierarchical systems. Computer J. 9: 373-380

Legendre, L., Legendre, P. (1979). Ecologie numérique. 1. Le traitement multiple des données écologiques. Masson, Paris, et les Presses de l'Université du Québec

Mackas, D. L. (1984). Spatial autocorrelation of plankton community composition in a continental shelf ecosystem. Limnol. Oceanogr. 20: 451-471

Matheron, G. (1974). Application de la théorie des variables régionalisées. Cah. C. M. M. Fontainebleau 5: 1-212

Pearson, T. H., Rosenberg, R. (1978). Macrobenthos succession in relation to organic enrichment and pollution of the marine environment. Oceanogr. mar. Biol. A. Rev. 16: 229-311

Princz, D., Menesguen, A., Glémarec, M. (1983). Temporal evolution over ten years in the macrobenthos of muddy sands in the Bay of Concarneau (France). In: Boutler, $T$. (ed.) Proceedings 17 th Eur. Mar. Biol. Symp. Oceanologica Acta (1983) vol. spéc., p. 159-163

Rees, E. I. S., Walker, A. J. M. (1983). Annual and spatial variation in the Abra community in Liverpool bay. In: Boutler, T. (ed.) Proceedings 17th Eur. Mar. Biol. Symp. Oceanologica Acta (1983) vol. spéc. p. 165-169

Sanders, H. L. (1960). Benthic studies in Buzzards Bay. III. The structure of the soft-bottom community. Limnol. Oceanogr. 5: $138-153$

Takens, F. (1981). Detecting strange attractors in turbulence. In: Rand, D. A., Young, L. S., (eds.) Dynamical systems and turbulence. Springer-Verlag, New York, p. 366-381

Warwick, R. M. (1986). A new method for detecting pollution effects on marine macrobenthic communities. Mar. Biol. 92: $557-562$

Warwick, R. M., Pearson, T. H., Ruswahyuni (1987). Detection of pollution effects on marine macrobenthos: further evaluation of the species abundance/biomass method. Mar. Biol. 95: $193-200$ 